\title{
Relatywizm. Pojęcie, rodzaje, podstawowe problemy ${ }^{1}$
}

\begin{abstract}
Relativism. The concept, types, basic problems

The issue of relativism is one of the basic issues raised by contemporary epistemology. The concept of relativism is important for pedagogical considerations for two reasons:

(I) discussions about relativism are, in some sense, controversial in relation to accepted values in "our" culture;

(II) pedagogy has philosophical foundations.

The multiplicity of approaches and semantic ambiguity of the problem of relativism may pose some interpretation difficulties. The aim of the text is to show and define possible types of relativism, with particular emphasis on the "strongest" version of epistemological relativism - alethic relativism.

Key words: relativism, alethic relativism, alethic absolutism, truth, epistemology Słowa kluczowe: relatywizm, relatywizm aletyczny, absolutyzm aletyczny, prawda, epistemologia

\section{Wstęp}

Problematyka relatywizmu stanowi jedno z podstawowych zagadnień podnoszonych przez współczesną epistemologię. Niezwykle istotne okazują się pytania o ścisłe znaczenie relatywizmu, jego źródła, odmiany i ewentualny zakres oddziaływania. To ostatnie zyskuje szczególny wymiar w świetle rozważań pe-

1 Niniejszy tekst stanowi zmodyfikowany przedruk fragmentu książki Dyskusja z relatywizmem prawdy w Szkole Lwowsko-Warszawskiej (Moroz, 2013a, s. 13-27).
\end{abstract}


dagogicznych, dla których dobrze sformułowane i znaczeniowo klarowne pojęcie relatywizmu może stanowić podstawę jego akceptacji bądź odrzucenia. Ma to swoje przełożenie na koncepcje pedagogiczne, których autorzy, mając na uwadze przede wszystkim rzetelność swojej pracy naukowej, muszą zadbać o ich spójność poprzez konsekwentny dobór i „teoretyczne uzgadnianie” odpowiednich założeń filozoficznych. Spór absolutyzmu z relatywizmem wydaje się tu szczególnie ważny, albowiem wartości epistemologiczne, ontologiczno-pojęciowe, jak również etyczne czy estetyczne zawsze pozostają w ścisłej relacji z koncepcjami kształcenia lub/i wychowania (por. Leś, 2017; Moroz, 2013b).

Prezentowany poniżej tekst ma przede wszystkim na celu ukazanie i zdefiniowanie możliwych rodzajów relatywizmu, ze szczególnym uwzględnieniem „najsilniejszej” wersji relatywizmu epistemologicznego - relatywizmu aletycznego.

\section{Pojęcie i rodzaje relatywizmu}

Relatywizm definiowany jest jako „pogląd filozoficzny, według którego wartości logiczno-poznawcze (prawda, fałsz), etyczne (dobro, zło) i estetyczne oraz związane z nimi normy i oceny mają charakter względny" ${ }^{2}$. Relatywizm przeciwstawiany jest absolutyzmowi. W języku potocznym relatywizm oznacza grupę przekonań stwierdzających zależność pewnego $x$ od $y$, na przykład: „temperatura w tym pokoju jest względnie wysoka”, „potrawa była względnie dobra” lub po prostu „x jest względny”. Termin „względny” można zastąpić terminem "relatywny”, nie zmieniając sensu wypowiedzi. W wymienionych przypadkach (i im podobnych) wyrażenie „względny” pojawia się w wypowiedziach mających opisać sytuacje zależnościowe. Mówiąc, że potrawa jest względnie dobra, „uzależniamy” jej jakość od czegoś wobec niej zewnętrznego, np. od aktualnego degustatora. Ocena jakości potrawy może się więc zmieniać w zależności od osoby ją spożywającej. Podobnie jest w przypadku dyskursu filozoficznego. Stwierdzenia typu: „dobro jest względne”, „prawda jest relatywna” itd., uzależniają powyższe wartości od rozmaitych czynników relatywizujących. A zatem zarówno w dyskursie potocznym, jak i naukowym użycie frazy „bycie względnym” (lub „bycie relatywnym”) występuje w podobnych okolicznościach, mianowicie takich, w których stwierdza się pewną zależność czegoś od czegoś innego. Ogólnym schematem relatywizmu jest prosta for-

\footnotetext{
2 Słownik wyrazów obcych (1995), s. 954.
} 
muła: „x jest relatywne do $y$ ”, gdzie za zmienną $x$ można podstawić prawdę, wiedzę, uzasadnianie, dobro, piękno lub układ pojęciowy itd., za $y$ zaś czynniki historyczne, kulturowe, społeczne, językowe, psychologiczne.

Istnieje wiele odmian relatywizmu filozoficznego, powstających w wyniku uzależniania istnienia pewnych $x$-ów (będących przedmiotem rozważań filozoficznych) od określonych czynników relatywizujących (czyli wspomnianych wyżej $y$-ów). Adam Chmielewski w pracy Niewspótmierność, nieprzekładalność, konflikt. Relatywizm we współczesnej filozofii analitycznej wyróżnił pięć typów relatywizmu: semantyczny, epistemologiczny, ontologiczny, etyczny i estetyczny. Relatywizm semantyczny to pogląd, że

(...) słowa jednego języka nie mogą być przekładalne na słowa innego języka w sposób nie powodujący utraty znaczenia. Głosi on więc zależność znaczeń słów od języka, w którym one występują, i niemożliwość - całkowitą lub częściową - oddawania znaczeń terminów jednego języka za pomocą terminów innych języków (Chmielewski, 1997, s. 50).

Relatywizm epistemologiczny „głosi zależność wyników aktów poznawczych od wyposażenia, usytuowania i stanu podmiotów poznania" (Chmielewski, 1997, s. 50). Relatywizm ontologiczny „orzeka zależność obowiązywalności twierdzeń o istnieniu określonych przedmiotów od odmiennych systemów pojęciowych. Każdy system czy schemat pojęciowy implikuje bowiem własną ontologię...” (Chmielewski, 1997, s. 51). Relatywizm etyczny „to stanowisko uznające względność ocen, sądów i wartości moralnych od systemów moralnych $\mathrm{w}$ zależności od systemów moralnych wyznawanych przez różne społeczeństwa” (Chmielewski, 1997, s. 51). Relatywizm estetyczny zaś „wskazuje na zależność ocen, sądów i wartości estetycznych od kultur, wspólnot i epok historycznych" (Chmielewski, 1997, s. 51).

W niniejszej pracy będę akceptował powyższy podział, z pewnymi modyfikacjami. W rozprawie Chmielewskiego zabrakło popularnego dziś terminu „relatywizm pojęciowy”. Jednakowoż znalazł się w niej termin „relatywizm ontologiczny”, który proponuję zastąpić terminem „ontologiczno-pojęciowy” lub po prostu „relatywizm pojęciowy” (wybór takiej terminologii zostanie dalej uzasadniony). Dodatkowo proponuję podzielić relatywizm epistemologiczny na trzy podkategorie: wiedzy, uzasadnienia i prawdy.

Osobną kwestią jest ustalenie relacji relatywizmu semantycznego do relatywizmu pojęciowego. Zgodnie z definicją zaproponowaną przez Chmielewskiego relatywizm semantyczny to teza, że język $J_{1}$ jest całkowicie lub częściowo nieprzekładalny na język $J_{2}$. Wszystkie zatem terminy, bądź ich część, pochodzące z jednego języka nie mają odpowiednika w języku drugim. Wydaje się, że

3 Ten schemat bywa wykorzystywany do eksplikacji, na bardzo ogólnym poziomie, stanowiska relatywistycznego. Zob. Swoyer (2010). 
tak pojęty relatywizm semantyczny łączy się z relatywizmem ontologicznym, albowiem zadaniem semantyki jest opisywanie relacji zachodzących między językiem a rzeczywistością pozajęzykową. Jeśli więc nie wszystkie terminy języka $\mathrm{J}_{1}$ dają się uzgodnić $\mathrm{z}$ terminami $\mathrm{J}_{2}$ (brak przekładalności), to można przypuszczać, iż dzieje się tak z powodu względności referencjalnej używanych terminów i zdań, to znaczy termin (bądź całe zdanie) z J odnosić się będzie do innych obiektów aniżeli termin (bądź zdanie) $\mathrm{z} \mathrm{J}_{2}$.

Zgodnie $\mathrm{z}$ tradycyjnym rozumieniem semantyki zadaniem używanych przez nas wyrażeń językowych jest odnoszenie się do jakiejś niejęzykowej rzeczywistości (przy czym jej określenie pozostaje tutaj kwestią wtórną). Desygnaty poszczególnych słów i stany rzeczy, do których odnoszą się zdania, istnieć więc muszą jako byty ekstralingwistyczne, a jako takie są od języka (i wszelkich układów pojęciowych) niezależne. Zakłada się więc tutaj istnienie obiektywnej rzeczywistości, o której język coś mówi.

Tak pojęta semantyka wyklucza pogląd, zgodnie z którym jakikolwiek język (w szerokim sensie), bądź terminy w nim występujące, mógłby „powoływać do życia" przedmioty obiektywnie istniejące - czyli takie, którym bylibyśmy skłonni przypisać status elementów autonomicznie istniejącej rzeczywistości Relatywizm semantyczny nie będzie implikował twierdzenia (w jakiejkolwiek postaci), że język istotnie wpływa na ontologię i, co się z tym wiąże, „stwarza” rzeczywistość pozajęzykową. Pełni on raczej funkcję medium między podmiotem poznającym a światem (niezależnie od możliwości jego poznania).

Relatywizm semantyczny będę rozumiał jako tezę głoszącą różnorodność sposobów językowego ujmowania „tej samej” rzeczywistości. Zgadzam się z twierdzeniem, że wieloaspektowość postrzeganego świata znacząco wpływa na mnogość i różnorodność języków. Niemniej teza o wielości światów, której konsekwencją byłby brak „fundamentu bytowego", nie bierze się z tego, że rzeczywistość jawi nam się jako różnorodna. Jeśliby przyjąć takie wyjaśnienie wielu obrazów rzeczywistości, faktycznie należałoby odrzucić istnienie świata samego w sobie. Wspomniana wieloaspektowość może zostać zobrazowana dwiema zupełnie różnymi wizjami świata: z jednej strony zdroworozsądkowego - składającego się ze stołów, drzew i kostek lodu, a z drugiej naukowego - wypełnionego cząstkami subatomowymi.

Nie wydaje się jednak, by taka wieloaspektowość była dobrą eksplikacją relatywizmu semantycznego. Powyższe przykłady, jak sądzę, trafniej będą oddawały istotę relatywizmu pojęciowego, dotycząc takich przypadków, w których względności pojęciowej towarzyszy zmienność ontologii (przejawiają-

4 Zakładając, że taka rzeczywistość jest poznawalna.

5 „Ta sama” rzeczywistość nie musi oznaczać „takiej samej”, albowiem nie jest wykluczone, że rzeczywistość podlega ciągłym zmianom, wciąż jednak pozostając tą samą. 
ca się właśnie $\mathrm{w}$ różnorodności obrazów świata). Relatywizm semantyczny dobrze oddają przykłady odmienności językowych znane z prac Benjamina Lee Whorfa i Edwarda Sapira. Ilustracje językowych zwyczajów Eskimosów, u których znajdziemy niespotykaną gdzie indziej wielość określeń śniegu, albo „brak” określeń czasu w języku Indian Hopi niekiedy wykorzystywane bywają do poparcia tezy o niejednorodności świata, a tym samym braku rzeczywistości samej w sobie.

Cechą charakterystyczną relatywizmu semantycznego jest „zależność znaczeń słów od języka, w którym one występują" (Chmielewski, 1997, s. 50). Różnice terminologiczne i znaczeniowe zachodzące pomiędzy na przykład językami europejskimi a językami Eskimosów i Indian Hopi wynikają z różnorodnych warunków życia, które mają odzwierciedlenie w używanym na co dzień języku. Nie chodzi tutaj zatem o jakiś rodzaj tworzenia rzeczywistości przez "nakładanie” na nią radykalnie odmiennych, a zarazem „równie dobrych”, schematów pojęciowych. Dlatego też relatywizm semantyczny nie implikuje tezy względności czy też braku „trwałej rzeczywistości”, którą można na różne sposoby upojęciawiać. Wspomniane wcześniej języki $J_{1}$ i $J_{2}$ opisują w różnych kategoriach „tę samą” rzeczywistość, nawet jeślibyśmy założyli, że języki te są wzajemnie nieprzekładalne. $W$ ramach relatywizmu semantycznego nie pojawia się więc teza ontologiczna, mówiąca o tym, jaki świat jest. Ta odmiana relatywizmu stwierdza jedynie istotne różnice w zasobie leksykalnym i/lub regułach gramatycznych języków etnicznych, co istotnie wpływa na pojęcia i sądy, które mogą zostać wygenerowane w danym języku.

Inaczej jest w przypadku relatywizmu pojęciowego (ontologiczno-pojęciowego) - dotyczy on klasy przedmiotów wyróżnionych przez dany schemat pojęciowy. System pojęciowy $\mathrm{S}_{1}$ generuje przedmioty $\mathrm{P}_{1}, \mathrm{~S}_{2}$ zaś - przedmioty $\mathrm{P}_{2}$. Nie można mówić o relatywizmie ontologicznym w sytuacji, gdy systemy pojęciowe są wzajemnie przekładalne, albowiem w takim przypadku u ich podłoża leży ta sama ontologia. Dlatego też z relatywizmem ontologicznym mamy do czynienia jedynie wówczas, kiedy dwa systemy pojęciowe są wzajemnie nieprzekładalne ${ }^{6}$. Nieprzekładalność jednego systemu pojęciowego na inny jest rezultatem zupełnie odmiennych ontologii. Jeśli $\mathrm{w}$ języku $\mathrm{J}_{1}$ nie znajdujemy odpowiednika dla terminu $\mathrm{t}_{2} \mathrm{z} \mathrm{J}_{2}$, oznacza to, że $\mathrm{J}_{2}$ zakłada istnienie obiektu $\mathrm{O}_{2}$, który nie istnieje w systemie $\mathrm{J}_{1}$. I tak, przyjęcie danego języka J automatycznie pociąga za sobą zgodę na jego ontologię. Takie rozumienie relatywizmu ontologicznego utożsamiam $\mathrm{z}$ tak zwanym relatywizmem pojęciowym.

6 Jak się wydaje, założenie o nieprzekładalności dwóch odmiennych schematów pojęciowych jest w tym przypadku konieczne, choć istnieje wiele argumentów na rzecz tezy przeciwnej. Prawdopodobnie dwaj fizycy reprezentujący odmienne systemy fizyczne znaleźliby wspólny punkt odniesienia w postaci danych obserwacyjnych. 
Ten, jak słusznie zauważa Maria Baghramian (por. Baghramian, 2005), nie jest motywowany empirycznymi badaniami (jak w przypadku relatywizmu semantycznego), lecz powstał raczej na podstawie teoretycznych analiz stosunku zachodzącego między umysłem, językiem a światem. Relatywizm pojęciowy stanowi następstwo filozoficznego założenia, że „świat nie jest gotowym wyrobem" (Baghramian, 2005, s. 163). Stąd relatywistami pojęciowymi są tacy współcześni filozofowie, jak Hilary Putnam, Richard Rorty czy Nelson Goodman $^{7}$. Głoszą oni zgodnie (przynajmniej w tej kwestii), że o świecie samym w sobie nie możemy nic twierdzić, a nawet że sama ta kategoria jest całkowicie niezrozumiała. Pojęcie „przedmiotu” ma sens jedynie w określonym układzie pojęciowym. Nie ma więc jednej wyróżnionej rzeczywistości. Można mówić o wielości światów, których istnienie uzależnione jest od przyjętej konceptualizacji. Co istotne, relatywizm ontologiczno-pojęciowy implikuje wiele równoważnych opisów rzeczywistości. Nie ma zatem jednej właściwej jej wersji albo przynajmniej jakiejś obiektywnej podstawy, względem której można by było (przyjmując eksternalną perspektywę) oceniać pod kątem słuszności dostępne wersje.

Klasyfikacja stanowisk relatywistycznych wymaga uprzedniego ustalenia, jakiego rodzaju obiekty podlegają relatywizacji, te bowiem wyznaczają możliwe typologie relatywizmu. W literaturze przedmiotu zwykle pisze się o obiektach, takich jak: prawda, wiedza, uzasadnienie, twierdzenia nauki, systemy pojęciowe (ontologie), przekonania, oceny itp. Wydaje się, że wszystkie wyżej wymienione obiekty są wartościami. „Wartością” będzie wszystko to, co jest przedmiotem pożądania ze względu na swoje walory czy bycie cennym. Przedmiot $\mathrm{P}$ stanowi zatem wartość dla osoby $\mathrm{O}$ ze względu na cechę C. „Wartość" jest własnością przysługującą danemu obiektowi lub obiektom, przypisywaną mu przez osobę bądź osoby ${ }^{8}$. Nie ma wątpliwości, że prawda, wiedza i uzasadnienie należą do wartości poznawczych. Jednak systemy pojęciowe (utożsamiane $\mathrm{z}$ ontologiami) również taką wartość przedstawiają, służąc do opisu rzeczywistości. Ponadto systemy te można wartościować ze względu na moc eksplanacyjną. Wartość poznawczą przypisuje się także twierdzeniom nauki. Przekonania, pojęte jako stany umysłu, pociągają za sobą akceptację danego

7 Poglądy Goodmana w kwestii istnienia świata zewnętrznego wydają się szczególnie radykalne. Relatywizacja dotyka tutaj nie tylko „prawdy”, ale nawet samej „rzeczywistości”. Jego filozofia odrzuca istnienie jednego realnego świata na rzecz wielu jego wersji. Wszystkie opisy rzeczywistości - naukowców, powieściopisarzy, artystów - są równie dobrymi opisami. Koncepcję tę Susan Haack proponuje określać mianem „irrealizmu”, który - jej zdaniem - wykazuje podobieństwo do społecznego konstruktywizmu. Zob. Haack (2004), s. 427.

8 Takie ujęcie sugeruje subiektywizm w teorii wartości, albowiem odwołuje się do doświadczenia jednostki. Moim celem nie jest rozstrzyganie kwestii, jak istnieją wartości - uznaję jedynie, iż wartością jest to, co za taką jest uznawane (słusznie bądź nie). 
sądu (treści zdania). Jako takie również należą do klasy wartości, albowiem uznanie sądu S jest wynikiem przypisania mu pewnej wartości. Ocena zaś jest stwierdzeniem wartości. Można zatem powiedzieć, że relatywizm pojawia się tam, gdzie istnienie pewnych wartości relatywizujemy, to jest uzależniamy od kontekstu, w którym funkcjonują. Kontekst tworzą: czas, miejsce, kultura, społeczeństwo, jednostka. Można przywołać wspomniany wcześniej schemat relatywistyczny: „x jest relatywne do $y$ ”, i ostatecznie określić, które obiekty należą do grupy relatywizowanych, a które do relatywizujących. Za $x$ można podstawić wszystkie wartości poznawcze, etyczne i estetyczne, za y zaś to, co określiłem mianem „kontekstu”, czyli czas, miejsce, kulturę, społeczeństwo, jednostkę itp.

Wielość czynników relatywizujących oraz obiektów relatywizowalnych, ponadto trudności w doprecyzowaniu niektórych pojęć powodują, że niełatwo jest podać dokładną i wyczerpującą typologię relatywizmu. Jej przedstawienie zawsze będzie pociągało za sobą konieczność redukcji i uproszczeń. Poniżej prezentuję moją propozycję taksonomii relatywizmów (również obciążoną wspomnianymi ograniczeniami). Jest ona próbą uporządkowania relatywizmów na potrzeby określenia miejsca relatywizmu prawdy wśród innych jego odmian.

1. Relatywizm pojęciowy (ontologiczno-pojęciowy). Istnienie klasy obiektów O jest zależne od systemu pojęciowego S. System pojęciowy $\mathrm{S}_{1}$ będzie generował obiekty $\mathrm{O}_{1}$, analogicznie klasa obiektów $\mathrm{O}_{2}$ jest rezultatem obowiązywania systemu $\mathrm{S}_{2}$. Zgodnie z tym relatywizmem ontologia jest implikowana przez dany system pojęciowy. Jednocześnie przyjmuje się założenie o niewspółmierności systemów pojęciowych.

2. Relatywizm semantyczny. Istnieją takie języki $\mathrm{J}_{1} \mathrm{i}_{2}$, że terminy i zdania języka $J_{1}$ nie mogą być wyartykułowane bez utraty znaczenia (całkowicie lub częściowo) w języku $\mathrm{J}_{2}$.

3. Relatywizm epistemologiczny. Wszystkie rezultaty aktów poznawczych zależą od wyposażenia, usytuowania i stanu podmiotów poznania.

a) Relatywizm wiedzy. Wiedza zależy od różnorodnych czynników relatywizujących, między innymi epoki, kultury, gatunkowych predyspozycji, indywidualnej perspektywy. Relatywizm wiedzy to zatem pogląd, że nie istnieje wiedza o charakterze uniwersalnym czy niekontekstowym.

b) Relatywizm uzasadnienia. Pojęcie uzasadniania ${ }^{9}$ jest ściśle związane z pojęciem wiedzy. Obok sporów na temat zasadności relatywizmu wiedzy to-

9 Termin „uzasadniać” za R. Chisholmem odnosić będę do oceny epistemicznej przekonań. Zob. Chisholm (1994), s. 25. Ponadto w stosunku do przekonań będę używał zamiennie 
czone są dyskusje o tym, czy istnieją obiektywnie skuteczne sposoby dowodzenia i procedury uzasadniania twierdzeń. Zgodnie z poglądami relatywistów wszystkie zależne są od kontekstu, w którym powstały (Baghramian, 2005, s. 116). Na kontekst składają się normy obowiązujące w danym czasie i miejscu, a nawet czynniki podmiotowe. Zatem różne społeczeństwa i kultury mają odmienne systemy uzasadniania swojej wiedzy i wszystkie one traktowane są przez relatywistów jako równoważne. Nie można więc powiedzieć, że któryś z systemów jest lepszy lub gorszy, nie istnieje obiektywny, uniwersalny sposób ich oceny.

c) Relatywizm prawdy. Prawdziwość danego sądu zależna jest od podmiotu, czasu i miejsca jego stwierdzania. Dwa sądy sprzeczne mogą być zarazem prawdziwe (np. dla różnych podmiotów).

4. Relatywizm etyczny. Wszystkie wartości moralne zależne są od przyjętego w danych kulturze/społeczeństwie/grupie systemu moralnego. Nie istnieją zatem uniwersalne wartości moralne.

5. Relatywizm estetyczny. Wszystkie wartości estetyczne zależne są od kultury/społeczeństwa/grupy społecznej. Nie istnieją zatem uniwersalne wartości estetyczne.

\section{Relatywizm prawdy}

Relatywizm prawdy, inaczej relatywizm aletyczny (gr. aletheia), można definiować zarówno w kategoriach twierdzenia, jak i zaprzeczenia (popularniejsza jest druga strategia). Mając na uwadze tę drugą perspektywę, relatywizm prawdy można przedstawiać jako antyabsolutyzm, antyobiektywizm i antyuniwersalizm, a niekiedy kontrastowany jest on również z realizmem.

Relatywizm aletyczny jednoznacznie odrzuca pogląd głoszący, że prawdziwość jest własnością absolutną (niezmienną, niestopniowaną, niezależną od okoliczności) sądów bądź zdań; innymi słowy, prawda nie ma charakteru absolutnego (antyabsolutyzm). Antyobiektywizm zakłada, że prawdziwość jako własność sądów/zdań nie przysługuje im niezależnie od podmiotów sądy te wydających. Konsekwencją antyuniwersalizmu jest brak powszechnej zgody w kwestii prawdziwości danego sądu. Oczywiście istnieje możliwość, że wszystkie podmioty zgodzą się co do tego, że sąd S jest prawdziwy, nie jest to jednak konieczne. Znane są przypadki relatywizmu aletycznego, kiedy to właśnie „Zgoda” określonej grupy osób ma decydować o prawdziwości sądu -

terminów „uzasadnienie” i „racjonalność”, gdzie „racjonalne przekonania” to przekonania dobrze uzasadnione. 
stanowiąc jedyne kryterium prawdziwości. Innymi słowy, antyuniwersalizm głosi, że możliwe są różne rozstrzygnięcia w sprawie prawdziwości danego sądu (może, ale nie musi być on za taki uznany).

Relatywizm aletyczny można także definiować pozytywnie, twierdząc, że prawdziwość jest względną własnością sądów (zależy od czasu, miejsca, okoliczności). W przypadku absolutyzmu aletycznego sąd jest prawdziwy lub nie, niezależnie od czasu, miejsca i okoliczności jego uznawania. Prawdziwość w tym ujęciu jest czymś obiektywnym i uniwersalnym, to jest niezależnym od wszelkich opinii. „Naturalnym” przeciwnikiem relatywizmu (prawdy) jest więc absolutyzm (prawdy).

W niniejszej pracy przyjmuję następujące definicje absolutyzmu i relatywizmu:

Absolutyzm aletyczny to pogląd, że prawdziwość sądu niezależna jest od czasu, miejsca lub podmiotu sądzącego. Prawda jest niestopniowalna i niezależna od okoliczności stwierdzania (wyjąwszy naturalnie te okoliczności, „o których” sąd mówi). Prawdziwość zdania „śnieg jest biały” jest oczywiście zależna od tego, że śnieg jest biały, ale nie od okoliczności formułowania tego zdania. W konsekwencji dwa sądy sprzeczne nie mogą być zarazem prawdziwe (Stępień, 1995, s. 138).

Relatywizm aletyczny to pogląd, że prawdziwość sądu zależna jest od czasu, miejsca lub podmiotu sądzącego. Dwa sądy sprzeczne mogą być zarazem prawdziwe (np. dla różnych podmiotów) (Stępień, 1995, s. 138).

Przyjęcie relatywizmu lub absolutyzmu wiąże się ściśle z akceptacją określonej koncepcji prawdy. Ogólnie rzecz ujmując, epistemiczne koncepcje prawdy (w szerokim sensie) uzależniają prawdziwość od możliwości jej rozpoznania. $\mathrm{W}$ tego typu teoriach zasadniczą rolę odgrywa tak zwana zasada poznawalności, zgodnie z którą ,jeśli zdanie jest prawdziwe, to w odpowiednich warunkach musi być możliwe poznanie, że jest ono prawdziwe" (Szubka, 2003, s. 80). Zatem pragmatyczne, konsensualistyczne, koherencyjne i epistemiczne teorie prawdy, opierając się na określonych kryteriach, to jest powszechnej zgodzie, użyteczności, uzasadnialności czy racjonalnej akceptowalności, wskazują, które sądy/zdania są prawdziwe, które zaś nie. Wymienione kryteria pozwalają niekiedy odróżnić zdania prawdziwe od nieprawdziwych. Koncepcje te często generują konsekwencje relatywistyczne ${ }^{10}$, wartość logiczna sądów/zdań uzależniona jest bowiem od różnych czynników relatywizujących, na przykład czasu, miejsca, grupy społecznej, a nawet jednostki. Klasyczna koncepcja prawdy, w odróżnieniu od kryterialnych, jest teorią absolutystyczną. Odróż-

10 Nie wszystkie koncepcje kryterialne należy klasyfikować jako relatywistyczne, nie są nimi: ewidencyjna w wersji Kartezjusza, Brentana i Rickerta, podobnie jak koherencyjna w wersji zaproponowanej przez Bradleya. Zob. Woleński (2005), s. 179. 
nia się w niej kryterium prawdy od jej definicji, prawdziwość traktując jako wartość nieepistemiczną. W ramach tej teorii prawdę rozumie się jako relację zgodnościową między jej nośnikiem a światem/rzeczywistością/faktem itp. „Prawdziwość” pojmowana jest jako relacyjna własność sądów/zdań/twierdzeń etc., a więc czegoś, co funkcjonuje w języku, będąc w relacji do czegoś pozajęzykowego. Stojąc na gruncie klasycznej koncepcji prawdy, przyjmuje się, że prawdziwość jej nośników zależy tylko i wyłącznie od tych fragmentów świata, „o których” nośnik traktuje, i żadne inne czynniki nie mają wpływu na wartość logiczną zdania.

Prawda jest własnością relacyjną, lecz nie jest relatywna. Jak słusznie zauważa Renata Ziemińska sąd: „Jestem dzisiaj w Lublinie”, mający treść dookreśloną przez kontekst, będąc raz prawdziwym, „staje się” takim na zawsze (Ziemińska, 2009, s. 304). „Prawdziwość” jest niestopniowalna, niezmienna, niezależna od podmiotu i okoliczności, nośnik prawdziwości zaś nie może być mniej lub bardziej prawdziwy - jest taki albo nie (Ziemińska, 2006, s. 121). Wyraźnie widać, że akceptując klasyczną koncepcję prawdy, zgadzamy się na absolutyzm w kwestii prawdziwości (Ziemińska, 2006, s. 121), nie jest to jednak zależność działająca w obie strony (dla przykładu wyidealizowany koherencjonizm można pogodzić $\mathrm{z}$ absolutyzmem prawdy).

Przystając na klasyczną formułę prawdziwości, zakładam istnienie „świata samego w sobie", mającego określoną strukturę ${ }^{11}$, niezależną od jakichkolwiek układów pojęciowych. Relacja korespondencji, zachodząca między tak pojętą rzeczywistością a naszym sądem, czyni go prawdziwym. Można jednak założyć, że nie zachodzi żadna korespondencja między sądem i rzeczywistością. W takim przypadku wszystkie wypowiedziane i pomyślane zdania okażą się fałszywe. Dla stanowiska absolutystycznego nie stanowi to najmniejszego zagrożenia.

Niekiedy uważa się, że absolutyzm prawdy implikowany jest przez relatywizm pojęciowy. Kwestie te rozważa Ziemińska, stwierdzając, że mimo iż prawdziwość zależy od świata i może pojawić się tylko w określonym układzie pojęciowym, to nadal pozostaje własnością absolutną sądów (mających ustaloną treść). Konkluduje więc, że relatywizm pojęciowy nie pociąga za sobą relatywizmu aletycznego (Ziemińska, 2009, s. 313-314). Z takim wnioskiem

11 W ramach prezentowanego poglądu można twierdzić, że istnieje coś, co Arthur Fine nazwał „głęboką strukturą świata”. Taka struktura nie jest dostępna eksperymentalnie, ale przyczynowo odpowiedzialna za nasze doświadczenia. Na gruncie tej koncepcji wyjaśnianie „sukcesu” teorii naukowej polega na przyjęciu, że aktualna struktura świata jest „obsługiwana” na poziomie doświadczenia tak, jakby dana teoria reprezentowała ją poprawnie. Nie rozstrzyga się tutaj (bo jest to niewykonalne), czy teoria faktycznie poprawnie reprezentuje strukturę rzeczywistości. Zob. Leplin (1997), s. 26. 
należy się zgodzić w przypadku obrania perspektywy realistycznej. Opowiadając się za istnieniem ustrukturyzowanej rzeczywistości, będziemy twierdzić, że od niej tylko zależy prawdziwość naszych sądów. Wówczas to nawet zgoda na wielość układów pojęciowych nie może zagrozić absolutyzmowi aletycznemu, gdyż wyłącznie jeden z nich może być układem właściwym (pozostałe będą generować sądy fałszywe). Sytuacja się komplikuje z chwilą przejścia na stanowisko antyrealistyczne, zgodnie z którym „świat nie jest gotowym wyrobem" (por. Putnam, 1998), a więc nie istnieje nic takiego jak określona i samoistna, niezależna od przyjętej ontologii, struktura rzeczywistości (antyrealizm ontologiczny). Tego typu pogląd odnajdujemy chociażby w filozofii Richarda Rorty’ego. Jego zdaniem pojęcie rzeczywistości samej w sobie jest sloganem zaczerpniętym z przestarzałego platońskiego żargonu (Rorty, 1996, s. 5052), podejmowanie zaś prób dochodzenia do istnienia bądź nieistnienia jakichś określonych stanów rzeczy wydaje się nieporozumieniem (Rorty, 1999a, s. 108). W Tekstach i grudkach Rorty podkreśla, że „twardość faktu” zależy od ustaleń danej wspólnoty co do następstw pewnych zdarzeń (Rorty, 1999b, s. 123). Z kolei w koncepcji „realizmu wewnętrznego” Hilarego Putnama odnajdujemy całkowite odrzucenie God's Eye point of view (por. Putnam, 1981, s. 49). Zależnie od tego, jakie znaczenie przypiszemy pojęciu „przedmiot”, taki będziemy mieli „świat” - kategoria rzeczy samych w sobie, tracąc swoją wartość i sens, przestaje już być potrzebna. W powyższych koncepcjach wyraźnie widoczne staje się utożsamianie systemu pojęciowego $\mathrm{z}$ ontologią - świat istnieje o tyle, o ile „tworzony” jest przez dany układ pojęciowy.

Obaj reprezentanci antyrealizmu metafizycznego, odrzucając istnienie rzeczywistości pozajęzykowej, odrzucają również koncepcję prawdy, opierającą się na relacji języka do rzeczywistości pozajęzykowej. Odejście od klasycznej koncepcji prawdy, na rzecz jakiejś jej odmiany pragmatycznej, w okolicznościach braku fundamentu odniesieniowego, jest w pełni zrozumiałe. W takim ujęciu prawdziwość sądów nie będzie więc zależała od transcendentnej rzeczywistości, ale na przykład od możliwości uzasadniania w danej wspólnocie lub bliżej nieokreślonej akceptowalności w wyidealizowanych warunkach. Jeśli więc relatywizm pojęciowy utożsamić $\mathrm{z}$ ontologicznym (jak czyni się w niniejszej pracy), to trzeba przyznać, że tak pojęty relatywizm pojęciowy/ontologiczny będzie implikował relatywizm prawdy.

Problem relatywizmu przeżywa dziś swój renesans. Widać to wyraźnie po wielości artykułów, w których rozważa się kwestie dotyczące możliwości obrony lub obalenia tego stanowiska. Duncan Pritchard (2006, s. 158) wskazuje na „relatywizm” jako pogląd, zgodnie z którym prawdziwe jest to, o czym myślimy, że jest prawdziwe. Akceptując tezę relatywizmu, każdej opinii nadajemy status bycia prawdziwą, wobec czego wszystkie opinie, nawet te sprzeczne, 
mogą być prawdziwe. Zdaniem Pritcharda takie stanowisko jest nie do utrzymania, gdyż samo się znosi. Również Harvey Siegel uważa, że relatywizm wciąż boryka się z zarzutem opartym na niespójności ${ }^{12}$, traktując go jako najpoważniejszy problem relatywistów (Siegel, 2004, s. 769). W Polsce pogląd podobny głosi Ziemińska, twierdząc, że relatywizm globalny, ze względu na brak punktu odniesienia, nie może być spójny (Ziemińska, 2009, s. 304). Globalny relatywizm aletyczny podlega samoznoszeniu się. Nieco inne stanowisko zajmuje Adam Grobler (por. Grobler, 2002). Stwierdza on, że najczęściej przytaczany $\mathrm{w}$ literaturze zarzut $\mathrm{z}$ samoodniesienia jest nieskuteczny, obowiązuje bowiem tylko, gdy staniemy na gruncie absolutyzmu. Grobler, wzorując się na koncepcji Tomasa Nagela „widoku znikąd”, odrzuca absolutyzm prawdy, jednocześnie akceptując jej obiektywność (Grobler, 2002, s. 15-17).

W niniejszym artykule przyjmuję, że relatywizm prawdy (aletyczny) to pogląd, zgodnie z którym prawdziwość, pojmowana jako własność sądów, będąc zależną od czasu, miejsca lub podmiotu poznającego, ma charakter względny. Dla tak pojętego relatywizmu charakterystyczne jest również to, iż prowadzi on do sprzeczności (dwa sądy sprzeczne mogą być zarazem prawdziwe). Relatywizm aletyczny nie jest tożsamy z relatywizmem pojęciowym ${ }^{13}$. Zgodnie z tym ostatnim istnieje wiele różnych układów pojęciowych, za pomocą których możemy odnosić się do świata. Zmiana układu pojęciowego nie pociąga za sobą zmiany wartości logicznej sądu, gdyż ta nie jest zależna od niego, lecz od rzeczywistości, do której się odnosi. Relatywizm aletyczny nie jest też implikowany przez relatywizm wiedzy lub uzasadniania. W obydwu przypadkach mamy do czynienia z wrażliwością na kontekst - w pierwszym wiedzy, w drugim uzasadnienia. Relatywizacja prawdziwości nie będzie więc konsekwencją żadnego z wyżej wymienionych relatywizmów. Na koniec dodać trzeba, że relatywizm aletyczny jest najbardziej radykalną odmianą relatywizmu epistemologicznego.

12 Siegel wskazuje na kilka odmian zarzutu samoznoszenia się relatywizmu. Najsilniejsza wersja mówi, że relatywizm wyklucza możliwość określenia prawdy, uzasadnienia albo - ogólnie rzecz ujmując - poznawczej wartości spornych twierdzeń lub tez, włączając w to sam relatywizm. Według krytykowanego stanowiska żadne twierdzenie nie może przejść testu epistemicznej współmierności lub być uznane za nieuzasadnione lub nieprawdziwe. Zob. Siegel (2004), s. 747-748.

13 Głoszonym z pozycji realizmu metafizycznego. 


\section{Zakończenie}

Pedagogika, będąc pełnowartościową dyscypliną akademicką, charakteryzuje się tym, iż nie ogranicza się jedynie do dyskursu stricte akademickiego, lecz wychodzi poza jego ramy, dostarczając rozwiązań praktycznych (wykorzystywanych w "konkretnych” sytuacjach wychowawczych, edukacyjnych itp.). Niemniej jako nauka ma niejako obowiązek, by proponowane przez nią praktyczne rozwiązania były rzetelnie osadzone w teorii naukowej. We wstępie do niniejszego tekstu sygnalizowałem już, że teorie pedagogiczne zawierają "mocne” osadzenie między innymi w problematyce filozoficznej. Taki stan rzeczy czyni dociekania pedagogiczne szczególnie wrażliwymi na transdyscyplinarny kontekst zawierający zagadnienia związane z pojęciami prawdy, wiedzy, uzasadniania, wartości etycznych itp. Nie można jednak odpowiedzialnie powoływać się na tego rodzaju kategorie, abstrahując od ich „naturalnego kontekstu", usytuowanego w rozważaniach epistemologicznych, etycznych, semantycznych itd. Nie możemy zatem odwołać się do pojęcia prawdy lub wiedzy (co w tekstach naukowych z pedagogiki nie należy do rzadkości) z pomięciem oferowanego przez nie dobrodziejstwa inwentarza, do którego należą ściśle określone filozoficzne założenia. I tak, jeśli opowiemy się za tradycyjnym rozumieniem prawdy, dokonamy wyboru na rzecz absolutyzmu aletycznego, wybierając zaś którąś z jej epistemicznych wersji automatycznie znajdziemy się na pozycjach relatywistycznych. Wobec powyższego uważam za szczególnie ważną kwestię filozoficznej orientacji pedagogów, samo zaś zagadnienie relatywizmu zarówno jako jedno z najważniejszych pojęć epistemologicznych, ale także relewantną kategorię pedagogiczną.

\section{Bibliografia}

Baghramian M. (2005). Relativism. Routledge. Taylor \& Francis Group e-Library, London-New York.

Chisholm R.M. (1994). Teoria poznania, tłum. R. Ziemińska. Daimonion, Lublin.

Chmielewski A. (1997). Niewspótmierność, nieprzekładalność, konflikt. Relatywizm we współczesnej filozofii analitycznej. Wydawnictwo Uniwersytetu Wrocławskiego, Wrocław.

Grobler A. (2002). Prawda a względność, wyd. II. Wydawnictwo Aureus, Kraków.

Haack S. (2004). Realism, w: I. Niiniluoto, M. Sintonen, J. Woleński (red.), Handbook of Epistemology. Kluwer Academic Publishers, Dordrecht. 
Leplin J. (1997). A Novel Defense of Scientific Realism. Oxford University Press, New York. Leś T. (2017). The Research Potential of Educational Theory: On the Specific Characteristics of the Issues of Education. „Educational Philosophy and Theory”, nr 49, 14.

Moroz J. (2013a). Dyskusja z relatywizmem prawdy w Szkole Lwowsko-Warszawskiej. Wydawnictwo Naukowe Scholar, Warszawa.

Moroz J. (2013b). Jaka koncepcja wiedzy jest „potrzebna” pedagogice?. „Kwartalnik Pedagogiczny", nr 2.

Pritchard D. (2006). What is This Thing Called Knowledge?. Routledge Taylor \& Francis Group. London-New York.

Putnam H. (1981). Reason, Truth and History. Cambridge University Press, Cambridge. Putnam H. (1998). Wiele twarzy realizmu i inne eseje, tłum. A. Grobler. Wydawnictwo Naukowe PWN, Warszawa.

Rorty R. (1996). Relatywizm: odnajdywanie i tworzenie, w: J. Niżnik (red.), Habermas, Rorty, Kołakowski: stan filozofii współczesnej. Wydawnictwo Instytutu Filozofii i Socjologii PAN, Warszawa.

Rorty R. (1999a). Pragmatyzm, w: T. Komendziński, A. Szachaj (red.), Filozofia amerykańska dziś. Wydawnictwo Uniwersytetu Mikołaja Kopernika, Torun.

Rorty R. (1999b). Teksty i grudki, w: R. Rorty, Obiektywność, relatywizm i prawda, tłum. J. Margański. Fundacja Aletheia, Warszawa.

Siegel H. (2004). Relativism, w: I. Niiniluoto, M. Sintonen, J. Woleński (red.), Handbook of Epistemology. Kluwer Academic Publishers, Dordrecht.

Stownik wyrazów obcych (1995). E. Sobol (red.). PWN, Warszawa.

Stępień A. (1995). Wstęp do filozofii. Wydawnictwo Naukowe Katolickiego Uniwersytetu Lubelskiego, Lublin.

Swoyer C. (2010). Relativism, w: Stanford Encyclopedia of Philosophy, http://plato. stanford.edu/entries/relativism/ (dostęp: 12.05.2010).

Szubka T. (2003). Epistemiczna koncepcja prawdy a relatywizm. „Filozofia Nauki”, nr 3-4. Woleński J. ( 2005). Epistemologia. PWN, Warszawa.

Ziemińska R. (2006). Czy można dziś obronić absolutyzm w teorii prawdy?, w: J. Jaskóła, A. Olejarczyk (red.), Prawda a metoda. Część II. O prawdzie. Wydawnictwo Uniwersytetu Wrocławskiego, Wrocław.

Ziemińska R. (2009). Spór relatywizmu z absolutyzmem na temat pojęcia prawdy. „Roczniki Filozoficzne”, t. LVII, nr 1. 